\title{
EPIDEMIOLOGICAL SITUATION OF PATIENTS ON THE WAITING LIST FOR CORNEAL TRANSPLANTATION: A SECTIONAL STUDY
}

\author{
SITUAÇÃO EPIDEMIOLÓGICA DE PACIENTES EM FILA DE ESPERA PARA O \\ TRANSPLANTE DE CÓRNEA: UM ESTUDO TRANSVERSAL
}

\author{
Giovanna Karinny Pereira CRUZ¹; Marcos Antonio Ferreira JÚNIOR²; \\ Isabelle Campos de AZEVEDO' ${ }^{\text {; }}$ Allyne Fortes VITOR ${ }^{2}$; Viviane Euzébia Pereira SANTOS ${ }^{2}$ \\ 1. Master's degree in Nursing, Universidade Federal do Rio Grande do Norte, Natal, RN, Brazil; 2. PhD, Professor of the Department of \\ Nursing in Graduate and Post-graduate courses (Master's and PhD) of the Universidade Federal do Rio Grande do Norte, Natal-RN, \\ Brazil.
}

\begin{abstract}
Describing the epidemiological characterization of patients awaiting cornea transplant (on the waiting list) of a reference service in the state of Rio Grande do Norte. A cross-sectional quantitative study conducted between January and April 2015 with patients on the waiting list $(n=62)$ registered by the Center for Notification, Collection and Distribution of Organs. Data were analyzed using the Statistical Package for the Social Sciences, version 20.0. Inferential analysis was carried out between the variable 'corneal disorder' and other variables of interest. Mean age of the patients was 49.68 years, and $54.84 \%$ were females. Keratoconus was the main initial condition found. The type of corneal disorder had a statistically significant association with the variables of gender and age. The keratoconus was the main indicator for cornea transplant. Factors such as age and gender may be related to the onset corneal endothelium disorders. We suggest that further studies be carried out in order to better evaluate the established association between the types of corneal disorders and the variables of gender and age, considering these may represent important epidemiological indicators for early detection of clinical manifestations and complications affecting the cornea in patients who are waiting for the corneal transplant.
\end{abstract}

PALAVRAS-CHAVE: Córnea. Ceratoplastia. Epidemiologia

\section{INTRODUCTION}

Corneal transplantation (CT) or keratoplasty is the primary method for visual rehabilitation, successfully repairing most of the causes of corneal blindness. It treats ocular diseases that affect the epithelium, stroma and corneal endothelium in order to promote restoring visual quality (ZESCHAU et al., 2012; TAN et al., 2012; BONFADINI et al., 2014).

The number of cornea transplants has declined since 201280.1 per million people (pmp) throughout Brazil, with a decrease of $5.2 \%$ (68.3 pmp) in 2014. However, despite waiting lists being regulated by the National Transplant System (SNT) for classifying potential recipients, they have also shown a decrease in recent years. This could have some explanations, such as the actual need being less than the estimated ( $90 \mathrm{pmp}$ ), or the patients not having access to transplant services (BRASIL, 2009; ABTO, 2012; 2014).

In Brazil, in cases where cornea transplant is indicated as a therapeutic condition, the patient is registered by a transplantation team into the Computerized Management System (GIS). Each State has its own Center for Notification, Collection and Distribution of Organs $(C N C D O)$ with a Single Technical Registry for corneal transplantation, since it is a non-vascularized tissue that does not require blood compatibility (BRASIL, 2009).

The selection of potential corneal receptors for transplant purposes is processed using severity criteria (urgent or elective), classification of the cornea to be used (optic or tectonic), donor's age group (donors who are 2 years of age or older and 80 years of age or younger), and waiting list time (in days). The items related to severity, classification of the cornea to be used and the donor's age group are informed by the transplant team (BRASIL, 2009).

Given this scenario, corneal transplantation is the object of this study as it is the most commonly performed transplantation procedure in the world, in addition to being the procedure that offers the highest healing and return of vision in cases of corneal blindness (BRASIL, 2009). In this perspective, the nursing care should include all surgical periods from patient indication to the transplant until their discharge. Nursing consultations can be used to identify risk factors, existing comorbidities, therapeutic adherence, appropriate use of medications, performance of physical eye examinations, and control of modifiable risk factors, thus ensuring improvement in the quality and transparency of the graft for a longer time (CRUZ et al, 2017). 
We hope the results of this study contribute to defining epidemiological indicators to identify the distribution and characterization of patients awaiting corneal graft. It can also promote care organization and planning to users on the waiting list, serving as a tool for surveillance, orientation and planning of actions by the National Transplant System and $C N C D O / R N$, in addition to encouraging training of health professionals in approaching this area.

This study aimed to describe the epidemiological characterization of patients on the waiting list for corneal transplant in the state of Rio Grande do Norte.

\section{MATERIAL AND METHODS}

This is an epidemiological, cross-sectional, descriptive and analytical study implementing a quantitative approach, carried out from January to April of 2015 together with the Center for Notification, Collection and Distribution of Organs of the State of Rio Grande do Norte $(C N C D O / R N)$, responsible for registering and controlling the database of patients on waiting list for transplants.

Sample calculation was not performed due to the logistic and operational feasibility to perform a census of the patients registered on the waiting list to perform corneal transplantation at the time of data collection. Thus, the sample consisted of all the patients in question with a sample totaling 62 patients who met the following eligibility criteria: individuals of all ages and gender followed within the study period, regardless of the clinical condition indicative for registration on the waiting list for corneal transplantation.

Data collection was conducted along with documentary records from the $C N C D O / R N$ after surveying the patients on the waiting list for cornea transplant. Collection involved a structured script specifically designed for this study in order to systematize the data collection necessary to meet the proposed objectives.

The structured script was designed to investigate the clinical and epidemiological variables; it contained closed questions filled out by the researcher with the data made available from the $C N C D O / R N$ database.

Data were processed and analyzed using the Statistical Package for Social Sciences (SPSS), version 20.0 and presented in tables. Descriptive statistics were used for univariate analysis using absolute and relative frequencies. Chi-square $\left(\mathrm{X}^{2}\right)$ or Fisher's exact tests were applied using a significance level of 0.05 for inferential analysis between the variable 'corneal disorder' with the variables gender, age, ethnicity, area of residence, mesoregion of the state, surgical aim/purpose and type of surgery.

Analyzed variables were gender, age, ethnicity, operated eye, surgical aim, ocular diagnosis, area of residence, mesoregion, disorder according to the affected layer of the cornea, surgery type and hospital type.

For the preparation of this article, the Strengthening the Reporting of Observational Studies in Epidemiology initiative (STROBE) was used, a checklist containing 22 items, called STROBE Statement, with recommendations on what should be included in a more precise and complete description of observational studies.

The study was partially funded by the Coordination of Improvement for Higher Education Personnel (CAPES) during the period from January to April 2015, through a scholarship granted by the CAPES Social Demand Program. The research protocol was approved by the Research Ethics Committee of the Federal University of Rio Grande do Norte regarding its ethical and methodological aspects, and in accordance with resolution CNS $\mathrm{n}^{\circ}$. 466/2012 under opinion 876.177 and CAAE number 37533014.8.0000.5537.

\section{RESULTS}

The general profile characterization of the 62 patients on the waiting list for transplants was as follows: $54.84 \%$ were female, $67.74 \%$ were of mixed raced, $93.44 \%$ of the patients lived in urban areas, and $38.71 \%$ were over 60 years of age.

Patients' mean age was 49.68 years of age (SD: 21.69), while half of the patients were up to 50.5 years. The average minimum and maximum donor age were 4.85 and 57.10 years, respectively.

Figure 1 shows the geographic distribution of patients on the waiting list according to initial indication and mesoregion of the State (Rio Grande do Norte). Of the 62 patients on the waiting list, 58 were from the state of the RN, while four patients were from other surrounding states. After scaling the cases by patient's area of residence, we found that $66.13 \%$ were distributed in the Leste Potiguar Mesoregion (Eastern region of the state), with the highest concentration of cases in the city of Natal (the State capital) and where the transplant teams, reference hospitals and $C N C D O$ are located. 


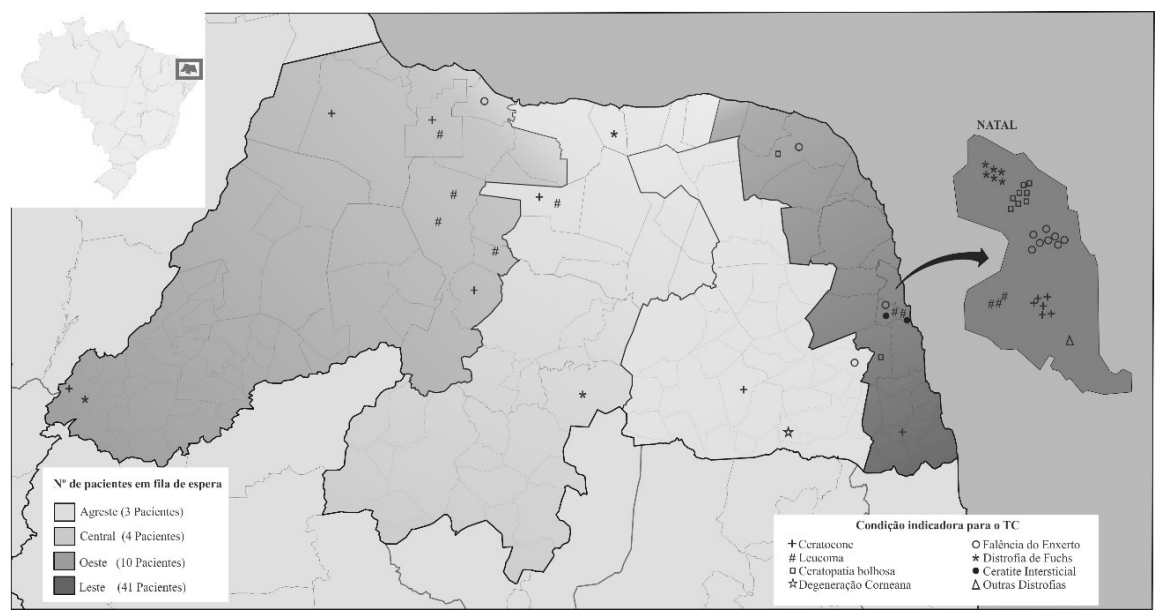

Figure 1. Geographic distribution of patients on the waiting list for cornea transplant according to indicated condition and mesoregion - Natal/RN, $2015(n=58)$

The clinical profile of the patients (Table 1) stands out in relation to the hospital type variable, where the private sector was responsible for $61.29 \%$ of the patients registered on the waiting list, with optical surgical purpose and elective surgery reaching $98.39 \%$ and $95.16 \%$, respectively.

Regarding main ocular diagnoses corresponding to the initial indication for transplant, the following results were obtained: keratoconus $(22.58 \%)$, late graft failure $(20.97 \%)$, leukoma of any etiology (17.74\%), bullous keratopathy $(17.74 \%)$ and Fuchs's dystrophy (14.52\%). Regarding the disorder according to the affected layer of the cornea, we found that $53.23 \%$ were endothelial disorders and $46.77 \%$ stromal disorders.

Table 1. Clinical profile of patients registered on the waiting list for cornea transplant - Natal $/ \mathrm{RN}, 2015(\mathrm{n}=$ 62).

\begin{tabular}{ll}
\hline Characteristics & $\mathbf{n}(\boldsymbol{\%})$ \\
\hline Type of hospital & $38(61.29)$ \\
$\quad$ Private & $24(38.71)$ \\
Public & \\
Eye to be operated & $38(61.29)$ \\
$\quad$ Right & $24(38.71)$ \\
Left & $61(98.39)$ \\
Surgical aim & $01(1.61)$ \\
Optical & \\
Tectonic & $59(95.16)$ \\
Surgical type & $03(4.84)$ \\
Elective & \\
Urgency & $14(22.58)$ \\
Ocular diagnosis & $13(20.97)$ \\
Keratoconus & $11(17.74)$ \\
Late graft failure & $11(17.74)$ \\
Leukoma of any etiology & $09(14.52)$ \\
Bullous keratoplasty & $02(3.23)$ \\
Fuchs's dystrophy & $01(1.61)$ \\
Interstitial keratitis & $01(1.61)$ \\
Corneal degeneration & \\
Other corneal dystrophies & \\
Type of corneal disorder & $33(53.23)$ \\
Endothelial disorders & $29(46.77)$ \\
Stromal disorders & $62(100)$ \\
Total &
\end{tabular}


The variable "type of corneal disorder" was isolated for calculating the probability of association. This corresponds to classifying the type of disorder according to the affected cornea layer, classified as epithelial, stromal or endothelial, which in turn was inferentially analyzed with the variables gender, age, ethnicity, area of residence, mesoregion of the state, surgical aim and surgery type, as shown in Table 2.

Table 2. Association between the variable "type of corneal disorder" versus characteristics of patients registered on the waiting list for cornea transplant - Natal/RN, $2015(n=62)$.

\begin{tabular}{|c|c|c|c|c|}
\hline \multirow[b]{2}{*}{ Characteristics of patients } & \multicolumn{4}{|c|}{ Type of corneal disorder } \\
\hline & $\begin{array}{l}\text { Stromal } \\
\mathrm{n}(\%)\end{array}$ & $\begin{array}{c}\text { Endothelial } \\
\mathrm{n}(\%)\end{array}$ & Total n(\%) & $p$-value \\
\hline \multicolumn{5}{|l|}{ Gender } \\
\hline Male & $17(60.71)$ & $11(39.29)$ & $28(100.00)$ & \multirow{2}{*}{$\underset{(1)}{0.046}$} \\
\hline Female & $12(35.29)$ & $22(64.71)$ & $34(100.00)$ & \\
\hline \multicolumn{5}{|l|}{ Age } \\
\hline Up to 20 years & $6(100.00)$ & $0(0.00)$ & $6(100.00)$ & \multirow{6}{*}{$\underset{(1)}{0.004}$} \\
\hline 21 - 30 years & $7(70.00)$ & $3(30.00)$ & $10(100.00)$ & \\
\hline $31-40$ years & $6(60.00)$ & $4(40.00)$ & $10(100.00)$ & \\
\hline $41-50$ years & $3(60.00)$ & $2(40.00)$ & $5(100.00)$ & \\
\hline $51-60$ years & $1(14.29)$ & $6(85.71)$ & $7(100.00)$ & \\
\hline Over 60 years & $6(25.00)$ & $18(75.00)$ & $24(100.00)$ & \\
\hline \multicolumn{5}{|l|}{ Ethnicity } \\
\hline Brown/Mixed & $19(45.24)$ & $23(54.76)$ & $42(100.00)$ & \multirow{3}{*}{$\underset{(1)}{0.554}$} \\
\hline White & $10(52.63)$ & $9(47.37)$ & $19(100.00)$ & \\
\hline Black & $0(0.00)$ & $1(100.00)$ & $1(100.00)$ & \\
\hline \multicolumn{5}{|l|}{ Area of residence* } \\
\hline Urban & $26(45.61)$ & $31(54.39)$ & $57(100.00)$ & \multirow{2}{*}{$\underset{(2)}{0.338}$} \\
\hline Rural & $3(75.00)$ & $1(25.00)$ & $4(100.00)$ & \\
\hline \multicolumn{5}{|l|}{ Mesoregion } \\
\hline Western & $8(80.00)$ & $2(20.00)$ & $10(100.00)$ & \multirow{5}{*}{0.155} \\
\hline Central & $2(50.00)$ & $2(50.00)$ & $4(100.00)$ & \\
\hline Central South & $2(66.67)$ & $1(33.33)$ & $3(100.00)$ & \\
\hline Eastern & 15 (36.59) & $26(63.41)$ & $41(100.00)$ & \\
\hline Other States & $2(50.00)$ & $2(50.00)$ & $4(100.00)$ & \\
\hline \multicolumn{5}{|l|}{ Surgical aim } \\
\hline Optical & $28(45.90)$ & $33(54.10)$ & $61(100.00)$ & \multirow{2}{*}{$\underset{(2)}{0.468}$} \\
\hline Tectonic & $1(100.00)$ & $0(0.00)$ & $1(100.00)$ & \\
\hline \multicolumn{5}{|l|}{ Surgical type } \\
\hline Elective & $26(44.07)$ & 33 (55.93) & $59(100.00)$ & \multirow{2}{*}{$\underset{(2)}{0.097}$} \\
\hline Urgency & $3(100.00)$ & $0(0.00)$ & $3(100.00)$ & \\
\hline
\end{tabular}

Evidence of statistical difference was found for "type of corneal disorder" and patient's gender and age variables. Regarding gender, a higher incidence of stromal corneal disorder was observed in males, whereas there was a predominance of endothelial disorders in females. By calculating the 
prevalence ratio (PR), we found that the occurrence of males with stromal disorder is 2.83 times higher than in females. Regarding the variable "age group", we found a predominance of endothelial disorders in individuals over 50 years.

\section{DISCUSSION}

The epidemiological profile of waiting list patients in the state of Rio Grande do Norte presented keratoconus as the main indication for corneal transplantation, and studies carried out in Brazil and Germany corroborate this result. National and international studies present keratoconus as one of the main corneal ectasias that result in CT as the therapeutic approach. However, indications for cornea transplant vary according to the different geographic locations and socioeconomic conditions of each population. In the state of Pernambuco, keratoconus is the second cause of indication for cornea transplant after leukoma, and the most frequent indication in Pará is associated with bullous keratopathy (ALMEIDA SOBRINHO; NEGRÃO; ALMEIDA, 2011; FEIZI, 2012; ALMEIDA; SOUZA, 2014; MACINTYRE, 2014) .

Population studies that present an epidemiological profile of waiting list patients or who underwent cornea transplant are recent and present results that differ according to location and population due to different public health conditions and existing socioeconomic levels (ALMEIDA SOBRINHO; NEGRÃO; ALMEIDA, 2011; FEIZI, 2012; WANG, 2013; ZESCHAU, 2013; ALMEIDA; SOUZA, 2014; MACINTYRE, 2014).

Corneal diseases present etiologies that cover infections, inflammatory diseases and degenerative diseases, and these can affect individuals of different age groups. In the present study, the prevalence of individuals over the age of sixty may be justified because the large number of corneal diseases is more evident with increasing age. Studies indicate that the mean age of patients undergoing cornea transplant varies according to the historical development of each region, its location and the increase in life expectancy. As the aging process advances, the number of corneal endothelial cells decreases. This physiological event justifies the statistical association established in this study between endothelial-type corneal disorders in individuals aged over 50 (ALMEIDA SOBRINHO; NEGRÃO; ALMEIDA, 2011; HILLENAAR; CLEYNENBREUGEL; REMEIJER, 2012; ZESCHAU, 2013; ALMEIDA; SOUZA, 2014; NANAVATY; WANG; SHORTT, 2014).
An association between endothelial and stroma disorders with gender was also found. Endothelial disorders had a greater association with females, probably related to the specific prevalence of some endothelial corneal diseases such as Fuch's dystrophy being greater in women. Another factor that may justify such association is Corneal Guttata (tiny drop-like lesions in the corneal endothelium called corneal guttata), which is a morphological variation characterized by nodular thickening in the corneal endothelium, and which usually arises after the age of 40 years with more prevalence in females (NANAVATY; WANG; SHORTT, 2014).

The association of stromal disorders with males was 2.83 times greater than in females. This result should be taken into account by future longitudinal studies due to the absence of studies investigating this association. To date, epidemiological studies classifying the types of disorders according to the affected corneal layer have not been found. Most studies focus on establishing a relationship between the variables and ocular diagnoses or conditions for cornea transplant (ALMEIDA SOBRINHO; NEGRÃO; ALMEIDA, 2011; ZESCHAU, 2013; ALMEIDA; SOUZA, 2014).

Regarding the $19.57 \mathrm{pmp}(\mathrm{n}=62)$ of waiting list individuals for cornea transplant, this is lower when compared to the number of patients on the waiting list in previous years (with $22.09 \mathrm{pmp}$ and $21.78 \mathrm{pmp}$ in 2013 and 2012, respectively. However, even with the decrease in the number of individuals indicated for cornea transplants, the estimated need is higher than the number of transplants performed each year. In 2014, 13,036 corneal transplants were performed in Brazil; however, the estimated need for that year was 17,168 transplants. At a rate of $50.2 \mathrm{pmp}$, the state of Rio Grande do Norte has not been able to maintain the level of cornea transplants close to the national (68.3 pmp) or Northeast region averages (50.8 pmp) (ABTO, 2012; 2013; 2014).

According to the National Transplantation Registry, cornea transplants continue to decline nationwide ( $7 \%$ compared to 2014 , and $21 \%$ to 2012) since the first quarter of 2015 , with short lists perhaps due to the decrease in the number of transplants from the use of new lenses and/or lack of access to transplantation centers (ABTO, 2015).

The distribution of the individuals on the waiting list with higher prevalence in the urban zone and Eastern Potiguar mesoregion concentrated in the city of Natal (the state capital, and where the $C N C D O$ and reference services are located), represents a possible justification for reducing the 
number of patients on the waiting list due to the lack of access of people from other regions to the reference services and the $C N C D O / R N$. Given this fact, we could conclude that the need for cornea transplants should be greater than that estimated annually in relation to the number of transplants performed.

Because this is a study with data collection originating from secondary data, it should be assumed that some biases may constitute limiting factors (as any study opting for this technique), such as the loss of important information, a certain degree of inaccurate data and weaknesses in the records and information systems used by the services. Ineligible or lost/misplaced medical records and incomplete records were excluded from the sample in order to minimize these limitations.

\section{CONCLUSIONS}

Distribution and epidemiological characterization of patients on the waiting list allowed us to understand the profile of these patients in the state of Rio Grande do Norte, presenting similarities and differences when compared to the other realities in the country from its main indication (keratoconus) to other variables such as gender, age group and distribution.

An association of the type of corneal disorder according to the affected layer between gender and age was verified among the studied characteristics. Therefore, we conclude that the aging process is directly related to the anatomical/physiological changes of the corneal layers, and consequently to the appearance of certain/specific corneal diseases. Thus, we suggest that further longitudinal studies are conducted with the aim of better evaluating the established association between types of corneal disorders and the variables of gender and age, considering that they can represent important epidemiological indicators for early detection of clinical manifestations of certain diseases and their respective complications for corneal tissue.

Moreover, it was noticeable that the geographic distribution of patients on the waiting list for corneal transplantation in the state of Rio Grande do Norte confirmed that the estimated number of transplants in the state is lower than the actual number due to the difficulty in accessing referral services.

Thus, through understanding the epidemiological profile of a given population, health professionals are able to problematize the reality, which allows us to identify epidemiological indicators that can be used as tools for surveillance, orientation and planning actions aiming to qualify patient care on a waiting list for corneal transplantation.

\section{Conflicts of interest}

The authors declare that there is no conflict of interest regarding the publication of this article. The submitting authors are responsible for coauthors declaring their interests.

\section{ACKNOWLEDGEMENTS}

Thanks to National Council of Technological and Scientific Development - CNPq and to Federal University of Rio Grande do Norte.

\section{REFERENCES}

ALMEIDA, H. G.; SOUZA, A. C. D. Epidemiological profile of patients waiting for penetrating keratoplasty in state of Pernambuco - Brazil. Revista Brasileira de Oftalmologia, v. 73, n. 1, p. 28-32, 2014. https://doi.org/10.5935/0034-7280.20140006

ALMEIDA SOBRINHO, E. F.; NEGRÃO, B. C.; ALMEIDA, H. G. Perfil epidemiológico de pacientes na fila de transplante penetrante de córnea no estado do Pará, Brasil. Revista Brasileira de Oftalmologia, v. 70, n. 6, p. 384-390, 2011. https://doi.org/10.1590/S0034-72802011000600009

Associação Brasileira de Transplante de Órgãos. Registro Brasileiro de Transplante Anual. 2012.

Associação Brasileira de Transplante de Órgãos. Registro Brasileiro de Transplante Anual. 2013.

Associação Brasileira de Transplante de Órgãos. Registro Brasileiro de Transplante Anual. 2014.

Associação Brasileira de Transplante de Órgãos. Registro Brasileiro de Transplante $2^{\circ}$ Trimestre. 2015. 
BONFADINI, G.; ROISMAN, V.; PRINZ, R.; SARLO, R.; ROCHA, E.; CAMPOS, M. Donation and waiting list for corneal transplantation en the State of Rio de Janeiro. Revista Brasileira de Oftalmologia, v. 73, n. 4, p. 237-242, 2014. https://doi.org/10.5935/0034-7280.20140051

BRASIL. Ministério da Saúde. Portaria n. 2.600, de 21 de outubro de 2009. Aprova o Regulamento Técnico do Sistema Nacional de Transplantes. Brasília; 2009.

BRASIL. Ministério da Saúde. Resolução nº 466 de 12 de dezembro e 2012. Dispõe sobre diretrizes e normas regulamentadoras de pesquisas envolvendo seres humanos. Diário Oficial da União, Brasil, DF, 11 de jun 2013. Seção 1, p.59.

CRUZ, G. K. P.; AZEVEDO, I. C.; CARVALHO, D. P. S. R. P.; VITOR, A. F.; SANTOS, V. E. P.; FERREIRA JÚNIOR, M. A. Clinical and epidemiological aspects of cornea transplant patients of a reference hospital. Revista Latino-Americana de Enfermagem, v. 25, n. 2897, p. 1-9, 2017. https://doi.org/10.1590/1518-8345.1537.2897

FEIZI, S.; EINOLLAHI, B.; YAZDANI S, HASHEMLOO A. Graft Biomechanical Properties After Penetrating Keratoplasty in Keratoconus. Cornea, v. 31, n. 8, p. 855-8, 2012. https://doi.org/10.1097/ICO.0b013e31823f8ce4

HILLENAAR, T.; CLEYNENBREUGEL, H. V.; REMEIJER, L. How Normal Is the Transparent Cornea? Effects of Aging on Corneal Morphology. Ophthlmology, v. 119, n. 2, p. 241-8, 2012. https://doi.org/10.1016/j.ophtha.2011.07.041

MACINTYRE, R.; CHOW, S.; CHAN, E.; POON, A. Long-term Outcomes of Deep Anterior Lamellar Keratoplasty Versus Penetrating Keratoplasty in Australian Keratoconus Patients. Cornea, v. 33, n. 1, p. 6-9, 2014. https://doi.org/10.1097/ICO.0b013e3182a9fbfd

NANAVATY, M. A.; WANG, X.; SHORTT, A. J. Endothelial keratoplasty versus penetrating keratoplasty for Fuchs endothelial dystrophy. Cochrane Database Systematic Reviews, v. 14, n. 2, p. 1-34, 2014. https://doi.org/10.1002/14651858.CD008420.pub3

TAN, D. T. H.; DART, J. K. G.; HOLLAND, E. J.; KINOSHITA, S. Corneal transplantation. Lancet, v. 379, n. 9827 , p. 1749-1761, 2012. https://doi.org/10.1016/S0140-6736(12)60437-1

WANG, J.; HASENFUS, A.; SCHIRRA, F.; BOHLE, R.M.; SEITZ, B.; SZENTMÁRY, N. Changing indications for penetrating keratoplasty in Homburg/Saar from 2001 to 2010--histopathology of 1,200 corneal buttons. Archivos Clinical \& Experimental Ophthalmology, v. 251, n. 3, p. 797-802, 2013. https://doi.org/10.1007/s00417-012-2117-2

ZESCHAU, A.; BALESTRIN, I. G.; STOCK, R. A.; BONAMIGO, E. L. Indications of keratoplasty: a retrospective study in a University Hospital. Revista Brasileira de Oftalmologia, v. 72, n. 5, p. 316-320, 2013. https://doi.org/10.1590/S0034-72802013000500007 